JACEK SIKORSKI

Uniwersytet Pedagogiczny im. Komisji Edukacji Narodowej w Krakowie

\title{
Diagnoza postępów w zakresie opanowania podstawowych umiejętności szkolnych uczennicy z umiarkowanym stopniem niepełnosprawności intelektualnej
}

\begin{abstract}
Jacek Sikorski, Diagnoza postępów w zakresie opanowania podstawowych umiejętności szkolnych uczennicy z umiarkowanym stopniem niepetnosprawności intelektualnej [The assessment of progress in acquiring the basic school skills by the student with a moderate intellectual disability]. Interdyscyplinarne Konteksty Pedagogiki Specjalnej, nr 22, Poznań 2018. Pp. 323-338. Adam Mickiewicz University Press. ISSN 2300-391X. DOI: https://doi.org/10.14746/ikps.2018.22.18

The following article takes up the issue of assessing intellectual disability from the interdisciplinary, especially psycho-pedagogical, point of view. It pays special attention to the moderate intellectually disabled students and the difficulties which they have in acquiring such basic school skills as reading, writing and counting. However, the main aim of the research was to show all the changes (progress) in the above-mentioned basic school skills in reference to the observed student with a moderate intellectual disability, which have occurred during the 10 months' time as a result of applying both educational and therapeutic actions and an attempt to indicate the school's education opportunities based on the results of the research and teacher's opinions.
\end{abstract}

KEY WORDS: psychological and pedagogical assessment, student's competences, student with intellectual disability 


\section{Wprowadzenie}

Proces diagnozy dziecka z niepełnosprawnością intelektualną, w odniesieniu do poszczególnych sfer rozwoju, wymaga uwzględnienia interdyscyplinarnego podejścia: medycznego, psychologicznego, pedagogicznego oraz społecznego' ${ }^{1}$.

Na gruncie pedagogiki specjalnej właściwie skonstruowana diagnoza pozwala $\mathrm{w}$ pełni poznać potrzeby dziecka $\mathrm{z}$ niepełnosprawnością, zarówno te o charakterze edukacyjnym, jak również terapeutycznym².

Diagnoza opiera się na:

- rozpoznawaniu zdolności i odchyleń w rozwoju na podstawie obserwowanych objawów,

- ustalaniu przyczyn mechanizmów i skutków nieprawidłowości rozwojowych i trudności w opanowaniu wiedzy i umiejętności. „Diagnoza obrazuje: tempo, rytm, dynamikę rozwoju dziecka"3.

Diagnoza powinna być jednoznaczna, trafna i rzetelna. Jej trafność oraz zalecenia (kwalifikacyjne oraz pedagogiczne) determinują oddziaływania o charakterze rewalidacyjnym ${ }^{4}$.

Diagnoza jest procesem interdyscyplinarnym, wiążącym się ze współdziałaniem specjalistów z wielu dziedzin (szczególnie psychologa i pedagoga), zatem postępowanie diagnostyczne jest długo-

${ }^{1}$ Por. L. Bobkowicz-Lewartowska L., Niepełnosprawność intelektualna. Diagnozowanie, edukacja i wychowanie, Harmonia Universalis, Gdańsk 2011, s. 60.

2 B. Trochimiak, U. Gosk, Diagnoza pedagogiczna uczniów ze specjalnymi potrzebami edukacyjnymi [w:] Dydaktyka specjalna w przygotowaniu do ksztatcenia uczniów ze specjalnymi potrzebami edukacyjnymi: podręcznik akademicki, red. J. Głodkowska, Wydawnictwo Akademii Pedagogiki Specjalnej, Warszawa 2012, s. 140.

${ }^{3}$ J. Hanisz, E. Grzegorzewska, Ocena opisowa rozwoju ucznia: ćwiczenia wspomagajace $i$ sprawdziany: ksztatcenie zintegrowane w klasach 1-3, Wydawnictwa Szkolne i Pedagogiczne Spółka Akcyjna, Warszawa 2008, s. 15.

${ }^{4}$ J. Głodkowska, Poznanie ucznia szkoły specjalnej. Wrażliwość edukacyjna dzieci upośledzonych umystowo w stopniu lekkim: diagnoza i interpretacja, Wydawnictwa Szkolne i Pedagogiczne Spółka Akcyjna, Warszawa 1999, s. 30. 
trwałe i wiąże się z dostosowaniem procedury badawczej do wieku i możliwości dziecka z niepełnosprawnością55.

Proces diagnozy realizowany w celu ukazania możliwości dziecka lub ewentualnych postępów w zakresie różnych umiejętności ma zawsze charakter specjalistyczny i, jak już wspomniano, wymaga współdziałania wielu specjalistów i zazwyczaj dokonuje się w warunkach poradnianych. Rezultaty postawionych diagnoz dają możliwość poznania przejawianych przez dane dziecko trudności, jak również wskazać przyczyny występujących problemów. Tak więc wielodyscyplinarna diagnoza daje szanse pełnego poznania możliwości dziecka, jego postępów w określonej sferze oraz przejawianych trudnoścí.

Biorąc pod uwagę charakter niniejszego opracowania, szczególnie istotne jest zwrócenie uwagi na proces diagnozy psychologiczno-pedagogicznej z punktu widzenia dziecka $\mathrm{z}$ niepełnosprawnością intelektualną w stopniu umiarkowanym.

Jak podkreśla Józef Sowa,

diagnoza psychopedagogiczna jest to stwierdzenie stanu rozwoju umysłowego, dokonane przez zespół specjalistów na podstawie rozpoznania uzyskanego w wyniku różnych metod i technik badawczych oraz analizy historii życia dziecka i jego sytuacji środowiskowej

Zatem w procesie diagnostycznym niezbędna jest stała współpraca pomiędzy specjalistami, szczególnie psychologiem i pedagogiem, gdyż:

- możliwości (psychofizyczne) badanego dziecka z niepełnosprawnością są uwarunkowane osobniczo, są nie w pełni poznane lub nieznane,

${ }^{5}$ A. Wójcik-Rudnicka, D. Kohut, Diagnoza psychologiczna i pedagogiczna czy psychopedagogiczna?, [w:] Dziecko o specjalnych potrzebach w kregu interdyscyplinarnej terapii, red. D. Kohut, Oficyna Wydawnicza „Impuls”, Kraków 2013, s. 91.

${ }^{6}$ B. Skałbania, Diagnostyka pedagogiczna. Wybrane obszary badawcze $i$ rozwiazania praktyczne, Oficyna Wydawnicza „Impuls”, Kraków 2011, s. 25-26.

7 J. Sowa, Pedagogika specjalna w zarysie, Wydawnictwo Oświatowe FOSZE, Rzeszów 1998, s. 111. 
- pod wpływem różnych bodźców dokonują się permanentne zmiany w rozwoju dziecka,

- występuje deficyt standaryzowanych narzędzi badawczych w odniesieniu do osób z niepełnosprawnością8.

W celu ukazania potencjału dziecka $\mathrm{z}$ niepełnosprawnością intelektualną lub zmian $\mathrm{w}$ odniesieniu do danej sfery (umiejętności), specjaliści: psycholog, jak i pedagog bazują na tak zwanych swobodnych technikach diagnozy (wywiad, rozmowa z rodzicami dziecka, obserwacja) oraz specyficznych - dostosowanych do wieku i możliwości badanego testach?

Celem diagnozy psychologicznej jest określenie poziomu funkcjonowania intelektualnego osoby badanej, procesów emocjonalnomotywacyjnych ${ }^{10}$, funkcji orientacyjnych i wykonawczych - percepcyjno-motorycznych, istotnych $\mathrm{z}$ punktu widzenia opanowania technik szkolnych takich jak: motoryka (mała i duża), percepcja wzrokowa, percepcja słuchowa, orientacja w przestrzeni, jak również w schemacie własnego ciała, określenie stronności (lateralizacji) a także współdziałania ze sobą wszystkich wspomnianych powyżej funkcji. Nie bez znaczenia jest również określenie stanu psychicznego oraz socjalizacji badanego dziecka ${ }^{11}$.

Na gruncie pedagogiki „przedmiotem diagnozy są trudności i niepowodzenia ucznia $\mathrm{w}$ procesie nabywania wiadomości i umiejętności szkolnych, ich przyczyny oraz ujemne konsekwencje dla rozwoju"12.

8 T. Oleńska-Pawlak, Struktura diagnozy psychopedagogicznej w rewalidacji indywidualnej, [w:] Diagnoza i rewalidacja indywidualna dziecka ze specjalnymi potrzebami edukacyjnymi, red. M. Klaczak, P. Majewicz, Wydawnictwo Naukowe Akademii Pedagogicznej, Kraków 2006, s. 8.

${ }^{9}$ A. Wójcik-Rudnicka, D. Kohut D, op. cit., s. 91.

10 B. Skałbania, Diagnostyka pedagogiczna. Wybrane obszary badawcze i rozwiazania praktyczne, Oficyna Wydawnicza „Impuls”, Kraków 2011, s. 26.

11 I. Czajkowska, Diagnoza i obserwacja pedagogiczna, [w:] Zajęcia korekcyjnokompensacyjne w szkole, I. Czajkowska, K. Herda, Wydawnictwa Szkolne i Pedagogiczne Spółka Akcyjna, Warszawa 1989, s. 52.

12 Ibidem, s. 51. 
Diagnoza pedagogiczna ma na celu:

- poznanie trudności przejawianych przez uczniów (zarówno w aspekcie edukacyjnym, jak i wychowawczym),

- ustalenie poziomu wiedzy oraz umiejętności w odniesieniu do obowiązującej podstawy programowej,

- określenie tempa przyswajania wiedzy,

- poznanie stosunku ucznia do obowiązków szkolnych, jego poziomu motywacji do podejmowania wysiłku intelektualnego ${ }^{13}$.

W diagnozie pedagogicznej zdaniem Ewy Górniewicz uwzględnia się następujące elementy:

- „rozpoznanie zjawiska,

- ocena tego zjawiska z punktu widzenia przyjętych standardów rozwojowych,

- prognoza rozwoju"14.

Jak podkreśla wspomniana powyżej autorka, w procesie diagnozy pedagogicznej należy wziąć pod uwagę:

- ocenę poziomu czytania - znajomość liter, umiejętność czytania głośnego (tekst bezsensowny, tekst wiązany), tempo czytania, technika czytania, poprawność czytania - identyfikacja oraz interpretacja błędów w czytaniu oraz rozumienie czytanego tekstu,

- ocenę poziomu pisania - przepisywanie, pisanie ze słuchu, z pamięci, ocena poprawności pisania wraz z interpretacją, ocena poziomu graficznego zapisu,

- diagnozé środowiska rodzinnego,

- diagnoze prognostyczną ${ }^{15}$.

W przypadku uczniów z niepełnosprawnością intelektualną rzetelna diagnoza mająca na celu ocenę postępów np. w nauce, wymaga od diagnosty pełnej znajomości procesu uczenia się wspomnianej grupy osób oraz przejawianych przez nich trudności, takich jak:

13 L. Bobkowicz-Lewartowska, op. cit., s. 60.

14 E. Górniewicz, Pedagogiczna diagnoza specyficznych trudności w czytaniu i pisaniu, Wydawnictwo Adam Marszałek, Torun 2009, s. 32.

15 Ibidem, s. 33-54. 
- wolne lub bardzo wolne tempo pracy,

- problemy ze skupieniem uwagi,

- zaburzenia mowy,

- trudności ze zrozumieniem wypowiedzi, poleceń, zadań,

- znacznie obniżona sprawność grafomotoryczna,

- zaburzona umiejętność dokonywania procesu analizy i syntezy,

- trudności w zakresie opanowania technik szkolnych (czytanie, pisanie, liczenie),

- utrudniony lub niski poziom rozumienia: treści zadań, czytanego tekstu, pojęć, zasad oraz definicji,

- trudności z zapamiętywaniem,

- mała samodzielność,

- utrudnione rozumowanie,

- brak motywacji do nauki szkolnej,

- słaba umiejętność wykorzystania zdobytej wiedzy w praktyce ${ }^{16}$.

Podczas dokonywania diagnozy pedagogicznej niezbędna jest również znajomość trudności przejawianych przez uczniów z niepełnosprawnością intelektualną $\mathrm{w}$ zakresie opanowania podstawowych technik szkolnych tj.: czytania, pisania oraz liczenia.

W literaturze podkreśla się, że trudności odnoszące się do podstawowych umiejętności szkolnych (czytanie i pisanie) uczniów z niepełnosprawnością intelektualną są konsekwencją ogólnego uszkodzenia intelektu i w dużym stopniu wynikają z nieprawidłowości w obszarze funkcji percepcyjno-motorycznych. Zauważa się, że trudności te nie zależą jedynie od stopnia zaburzeń psychoruchowych, ale również od etapu edukacyjnego dziecka. Szczególnie na pierwszym etapie, czyli edukacji wczesnoszkolnej, zauważa się trudności w zapamiętywaniu poszczególnych liter alfabetu i łączenia ich z danym dźwiękiem. Podczas czytania i pisania uczniowie $\mathrm{z}$ niepełnosprawnością intelektualną (w stopniu lekkim) mylą litery

16 P. Jurkiewicz, B. Rola, Model pracy z uczniem upośledzonym umysłowo w stopniu lekkim, Podniesienie efektywności kształcenia uczniów ze specjalnymi potrzebami edukacyjnymi. Materiały szkoleniowe część II, Ministerstwo Edukacji Narodowej, Warszawa 2010, s. 139-140. 
o podobnym brzmieniu i znaku graficznym. Ponadto obserwuje się występowanie takich błędów, jak: dodawanie wyrazów, liter lub sylab, a także ich przestawianie bądź opuszczanie. Technika czytania jest dość obniżona, zazwyczaj dominuje technika sylabizowania bądź literowania (głoskowania) oraz trudności z dokonywaniem procesu syntezy czytanych wyrazów. Czytanie i pisanie przebiega w bardzo wolnym tempie. Obniżona technika czytania, wolne tempo oraz popełniane błędy uniemożliwiają zrozumienie czytanego tekstu. Duże problemy sprawia uczniom z niepełnosprawnością intelektualną opanowanie umiejętności poprawnego pisania. Zazwyczaj obserwuje się błędy techniczne, typowo ortograficzne, gramatyczne oraz leksykalne. Kreślone litery są niekształtne, a pismo bardzo nierówne, drżące. Występują również problemy z przestrzeganiem w pisowni zasad ortografii. Warto dodać, że współwystępujące u wspomnianej grupy uczniów zaburzenia mowy, w dużym stopniu przekładają się na opanowanie wspomnianych technik szkolnych ${ }^{17}$.

Uczniowie $\mathrm{z}$ niepełnosprawnością intelektualną w stopniu lekkim, a szczególnie w stopniu umiarkowanym wykazują również trudności w przyswajaniu treści z zakresu matematyki.

Trudności te uwidaczniają się szczególnie w takich aktywnościach, jak: dostrzeganie podobieństw (analogii), uogólnianie, umiejętności wykorzystania algorytmów, matematyzowaniu, jak również w naśladowaniu, dostrzeganiu prawidłowości oraz schematyzowaniu. Wykazują trudność ze zrozumieniem pojęcia liczby, opanowania liczb z zakresu pierwszej dziesiątki, a także wykonywaniu działań na liczbach. Uczniowie ze wspomnianą niepełnosprawnością pracują wolno, dość niepewnie, wymagają aprobaty ze strony nauczyciela, mają problem z korektą błędów wskazanych w zadaniu'18.

17 G. Tkaczyk, Metodyka nauczania i wychowania poczatkowego w szkole specjalnej, Wydawnictwo Uniwersytetu Marii Curie-Skłodowskiej, Lublin 1997, s. 294-296.

${ }^{18} \mathrm{H}$. Siwek, Możliwości matematyczne uczniów szkoty specjalnej. Zarys teorii i propozycje rozwiązań metodycznych, Wydawnictwa Szkolne i Pedagogiczne, Warszawa 1995, s. 5-27, 60. 
Zatem proces diagnozy ucznia z niepełnosprawnością intelektualną (szczególnie w stopniu umiarkowanym) dokonywany w celu ukazania jego możliwości lub potencjalnych zmian w zakresie danej umiejętności wymaga uwzględnienia indywidualnych zdolności osoby badanej, dostosowania narzędzi badawczych, (a właściwie ich samodzielnego opracowania) stałej obserwacji podejmowanych aktywności, podążania za tokiem pracy dziecka.

Wynikiem końcowym rzetelnie przeprowadzonej diagnozy jest określenie poziomu funkcjonowania dziecka ze wspomnianą niepełnosprawnością (wskazanie jego możliwości oraz przejawianych trudności, ukazanie zmian, postępów) w zakresie różnych umiejętności. Rezultaty przeprowadzonej diagnozy stanowić będą podstawę do planowania wobec ucznia działań o charakterze edukacyjnym oraz terapeutycznym.

\section{Metodologia badań własnych}

Wyniki przeprowadzonych diagnoz psychologiczno-pedagogicznych (najczęściej prezentowane $\mathrm{w}$ orzeczeniu o potrzebie kształcenia specjalnego) w dużym stopniu determinują dyskusję, co do dalszej drogi kształcenia uczniów z niepełnosprawnością intelektualną. Dlatego też celem badań było poznanie zmian (postępów), jakie nastąpiły $\mathrm{w}$ zakresie opanowania podstawowych umiejętności szkolnych $\mathrm{u}$ dziewczynki z niepełnosprawnością intelektualną $\mathrm{w}$ stopniu umiarkowanym, w młodszym wieku szkolnym, w wyniku prowadzonych działań edukacyjnych i terapeutycznych oraz próba wskazania możliwości (formy) kształcenia badanej uczennicy na podstawie uzyskanych wyników oraz opinii nauczyciela.

Zatem sformułowano następujące pytanie badawcze:

Jaka zmiana $\mathrm{w}$ zakresie podstawowych umiejętności szkolnych: czytania pisania oraz liczenia nastąpiła na przełomie 10 miesięcy od pierwszego pomiaru u badanej uczennicy w wyniku prowadzonych działań edukacyjnych oraz terapeutycznych? 
Zastosowaną metodą badawczą była metoda indywidualnych przypadków. W ramach wspomnianej metody dokonano analizy dokumentów: opinii medycznej, orzeczeń o potrzebie kształcenia specjalnego, opinii szkół oraz opinii logopedycznej, na podstawie których skonstruowano charakterystykę badanego dziecka. Diagnoza pedagogiczna (zarówno pierwsza jaki i druga) została przeprowadzona przez autora artykułu na terenie jednej z poradni psychologiczno-pedagogicznej znajdującej się na terenie województwa małopolskiego. W diagnozie pedagogicznej zastosowano wewnętrzne narzędzia badawcze stosowane $\mathrm{w}$ poradniach, a także wybrane karty pracy zawarte w publikacji Diagnoza rozwoju ucznia z niepetnosprawnościa intelektualna w stopniu umiarkowanym: karty pracy, autorstwa Alicji Tanajewskiej oraz Renaty Naprawy. Przeprowadzona diagnoza pozwoliła określić postęp (zmiany) w zakresie opanowania podstawowych technik szkolnych (czytanie, pisanie oraz liczenie) u badanej dziewczynki z niepelnosprawnością intelektualną $\mathrm{w}$ stopniu umiarkowanym.

Osobą badaną była uczennica z niepełnosprawnością intelektualną $\mathrm{w}$ stopniu umiarkowanym, $\mathrm{w}$ młodszym wieku szkolnym, uczęszczająca do klasy integracyjnej. Placówka, do której uczęszcza dziewczynka, mieści się na terenie województwa małopolskiego. Szczegółowe informacje na temat badanej uczennicy zostały zaprezentowane poniżej.

\section{Analiza indywidualnego przypadku}

Jak już wspomniano, osobą badaną była dziewczynka w młodszym wieku szkolnym ze zdiagnozowaną niepełnosprawnością intelektualną w stopniu umiarkowanym, uczęszczająca do szkoły podstawowej z oddziałami integracyjnymi.

Z pierwszych opinii szkół do których uczęszczała uczennica wynika, że początkowo dziewczynka była wycofana, nie podejmowała aktywności komunikacyjnej z rówieśnikami, nie uczestniczyła w zabawach kolegów oraz koleżanek. Podczas lekcji nie wykazywała aktywności, pracowała wolno, wymagała pomocy ze strony nauczyciela w trakcie realizacji zadań. Miała dużą trudność z identyfi- 
kacją liter oraz cyfr. $Z$ czasem zauważono postęp w zakresie technik szkolnych, szczególnie pisania (odwzorowywanie liter, prawidłowe ich łączenie oraz mieszczenie liter w liniaturze), jednakże czytanie oraz przyswajanie treści z zakresu matematyki $\mathrm{w}$ dalszym ciągu stanowiło dość dużą trudność. Przejawiała również problemy $z$ koncentracją uwagi oraz ze zrozumieniem poleceń. $W$ celu poprawy sytuacji dziewczynka uczestniczyła $\mathrm{w}$ zajęciach wyrównawczych. Zauważono, że w odmienny sposób reaguje $\mathrm{w}$ trakcie zajęć indywidualnych - wyraźnie nawiązuje kontakt $\mathrm{z}$ nauczycielem, jest zdecydowanie bardziej otwarta, podejmuje aktywność werbalną.

U badanej uczennicy zdiagnozowano: mutyzm oraz oligofazję. Z opinii logopedycznej wynika, że wypowiedzi dziewczynki są dość ubogie chaotyczne, występuje trudność z ich konstruowaniem. Ponadto $\mathrm{w}$ wymowie badanej zauważa się:

- elizje,

- substytucje,

- uproszczenia grup spółgłoskowych,

- ubezdźwięcznienia,

- zaburzoną artykulację głosek syczących.

Poza tym zauważono obniżoną ruchomość aparatu artykulacyjnego oraz dość duże nieprawidłowości w zakresie analizy i syntezy słuchowej wyrazów.

W celu dokładnego zobrazowania możliwości intelektualnych uczennicy skupiono się na prezentacji wyników dwukrotnie przeprowadzonych diagnoz psychologicznych, jak również pedagogicznych, ze szczególnym wyróżnieniem zmian w zakresie opanowania podstawowych umiejętności szkolnych: czytania, pisania oraz liczenia.

\section{Wynik pierwszego badania psychologicznego}

Wynik pierwszego badania psychologicznego wskazuje na niepełnosprawność intelektualną uczennicy w stopniu umiarkowanym (pierwsze orzeczenie o potrzebie kształcenia specjalnego wydane z diagnozą: niepełnosprawność intelektualna w stopniu lekkim, ze 
względu na fakt, iż było to pierwsze badanie dziecka). Ponadto z przeprowadzonego badania psychologicznego wynika, że uczennica przejawia trudności z:

- myśleniem abstrakcyjnym, przyczynowo-skutkowym,

- dokonywaniem szczególnie takich operacji umysłowych, jak: abstrahowanie i uogólnienie, co przekłada się na umiejętność tworzenia pojęć,

- myśleniem w oparciu o analogię,

- wnioskowaniem,

- zapamiętywaniem,

- ze zrozumieniem poleceń.

Zauważono również zaburzenia $\mathrm{w}$ zakresie słuchowej pamięci fonologicznej.

Ponadto uczennica przejawia trudności komunikacyjne - wykazuje problem z formułowaniem wypowiedzi, odznacza się niskim zasobem słownictwa.

Z badania psychologicznego wynika, że dziewczynka jest osobą życzliwą spokojną, przejawiającą pozytywne nastawienie do otaczającej rzeczywistości.

\section{Wynik pierwszego badania pedagogicznego}

Przeprowadzone badanie pedagogiczne wykazało, że dziewczynka:

- nie potrafi czytać - trudności w czytaniu wynikają z niepełnej znajomości liter oraz nieumiejętności dokonania procesu syntezy wyrazów;

- rozumie treści krótkich opowiadań (prezentowanych przez osobę badająca), aczkolwiek w trakcie formułowania odpowiedzi wymaga podpowiedzi - pytań naprowadzających;

- przejawia trudności w pisaniu - występuje problem z odtwarzaniem kształtu graficznego liter (małych oraz wielkich), zapis wyrazów jest nieprawidłowy - zniekształcony;

- nie opanowała podstawy programowej z języka polskiego z klasy I oraz II szkoły podstawowej; 
- z zakresu umiejętności matematycznych dziewczynka nie opanowała w pełni liczenia w zakresie drugiej dziesiątki (wykazywała trudność z rozpoznawaniem niektórych liczb) nie identyfikuje wszystkich podstawowych figur geometrycznych, aczkolwiek rozumie stosunki przestrzenne, klasyfikuje, porównuje przedmioty, liczebności zbioru, dokonuje operacji na liczbach (dodawanie i odejmowanie liczb z przekroczeniem progu dziesiątkowego) w oparciu o konkret;

- pracuje w wolnym tempie;

- wykazuje trudności komunikacyjne.

Podczas badania pedagogicznego uczennica nie wykazywała aktywności werbalnej, była bardzo onieśmielona, wymagała motywowania, pełnego instruowania, podpowiedzi ze strony osoby badającej.

W zaleceniach orzeczenia o potrzebie kształcenia specjalnego zwrócono m.in. uwage na konieczność dostosowania procesu edukacyjnego (treści, metod kształcenia, form oraz środków dydaktycznych) do indywidualnych możliwości uczennicy, a także uczestnictwa w zajęciach terapeutycznych: rewalidacyjnych oraz logopedycznych.

Kolejne badanie psychologiczno-pedagogiczne nastąpiło po około 10 miesiącach od pierwszego badania. Zatem jakie zmiany, szczególnie w zakresie technik szkolnych (czytania, pisania oraz liczenia), zaobserwowano u badanej uczennicy w wyniku prowadzonych działań edukacyjnych i terapeutycznych na terenie szkoły?

\section{Wynik drugiego badania psychologicznego}

Wynik ponownego badania psychologicznego potwierdził u uczennicy niepełnosprawność intelektualną w stopniu umiarkowanym. Ponadto badanie psychologiczne ujawniło, że:

- rozwój uczennicy przebiega nieharmonijnie;

- lepsze wyniki dziewczynka uzyskuje w takich kategoriach, jak: 
- sytuacje społeczne - ich rozumienie,

- uczenie się wzrokowo-ruchowe,

- zauważanie takich relacji, jak: część-całość;

natomiast słabsze wyniki uzyskuje w takich kategoriach, jak:

- rozumowanie na materiale werbalnym oraz niewerbalnym,

- wiadomości ogólne oraz zasób słownictwa;

- funkcje wzrokowe uczennicy są osłabione, natomiast funkcje percepcyjno-motoryczne-słuchowe zaburzone;

- uczennica nie podejmuje się wykonania zadań dla niej trudnych.

W kontakcie z druga osoba dziewczynka uśmiecha się, podejmuje próby komunikacji - szczególnie niewerbalnej (mowa ciała, gest).

\section{Wynik drugiego badania pedagogicznego:}

Wynik ponownego badania pedagogicznego ujawnił, że:

- u badanej uczennicy w dalszym ciągu utrzymują się trudności w czytaniu, aczkolwiek zauważa się w tym zakresie postęp. Dziewczynka zaczęła czytać proste jednosylabowe wyrazy, dokonując ich syntezy;

- podobnie jak podczas pierwszego badania, zaobserwowano, że uczennica jest w stanie skoncentrować się na prezentacji krótkiego tekstu i udzielić odpowiedzi na wskazane przez badającego pytania, udzielone odpowiedzi sugerują prawie pełne zrozumienie przez badaną tekstu;

- zauważono, że uczennicy nie sprawia większej trudności ułożenie historyjki obrazkowej oraz skonstruowanie prostych zdań na jej temat;

- badana w dalszym ciągu wykazuje trudności w pisaniu. Zauważono trudność szczególnie z pisownią dwuznaków. Pozostałe litery kreślone są $\mathrm{w}$ większości poprawnie. W ramach przeprowadzonych prób pisania zaobserwowano trudności z zapisem prostych wyrazów ze słuchu oraz z pamięci. Natomiast pisanie ze wzoru nie sprawiało uczennicy trudności; 
- nastąpiły zauważalne zmiany w zakresie umiejętności matematycznych - dziewczynka opanowała umiejętność liczenia blisko do 100 oraz zapis liczb prawie do 40 oraz podejmuje próby mnożenia. W dalszym ciągu dokonuje operacji na liczbach jedynie w oparciu o konkret;

- u uczennicy nastąpiła poprawa w zakresie komunikacji. Dziewczynka jest bardziej otwarta. Konstruując wypowiedź, w dalszym ciągu bazuje na pojedynczych wyrazach, aczkolwiek zaczyna wypowiadać się już pełnym zdaniem.

Podczas badania zauważono duże zmiany w zachowaniu uczennicy. Badana była uśmiechnięta, chętnie współpracowała, zadania wykonywała z zaangażowaniem. Aczkolwiek wymagała stałej obserwacji, podpowiedzi, ukierunkowania ze strony osoby badającej.

Z opinii pedagoga specjalnego pracującego na co dzień z uczennicą wynika, że trudności w zakresie technik szkolnych: czytania oraz pisania nadal się utrzymują, chociaż nauczyciele oraz terapeuci zauważają progres w tym zakresie. Nie tylko w sferze edukacyjnej, ale również w emocjonalnej, a także pod kątem rozwoju mowy.

\section{Konkluzje końcowe}

Jak już wspomniano, celem prowadzonych badań było poznanie zmian, jakie dokonały się u badanej uczennicy z niepełnosprawnością intelektualną $\mathrm{w}$ stopniu umiarkowanym na przestrzeni 10 miesięcy od pierwszego pomiaru $\mathrm{w}$ zakresie opanowania podstawowych umiejętności szkolnych, w wyniku realizowanych działań edukacyjnych i terapeutycznych oraz próba określenia możliwości kształcenia na podstawie uzyskanych wyników oraz opinii nauczyciela.

Wynik przeprowadzonej diagnozy pedagogicznej potwierdził niewielki, choć znaczący postęp dziewczynki w zakresie opanowania technik szkolnych (czytania pisania oraz liczenia), który jest 
składową podejmowanych działań edukacyjnych i terapeutycznych, realizowanych zarówno na terenie szkoły oraz w środowisku pozaszkolnym. Istotny jest fakt zauważalnego progresu w tym zakresie, co potwierdzają nauczyciele i specjaliści pracujący na co dzień z uczennicą. Po okresie 10 miesięcy pierwszym sygnałem zaistniałych zmian $w$ funkcjonowaniu dziecka był znaczący progres w zakresie komunikacji. Dziewczynka chętnie współpracowała, udzielała odpowiedzi na zadawane pytania, pracowała wytrwale i zaangażowaniem. Jednak dało się zauważyć, co podkreśla również pedagog specjalny pracujący z uczennicą, że podczas wykonywanych zadań dziewczynka wymaga stałego nadzoru, ukierunkowania podejmowanych działań, co świadczy o niepełnej zdolności uczennicy do samodzielnej pracy (w tym również na lekcji). Zatem należy postawić pytanie, czy edukacja badanej uczennicy $\mathrm{z}$ niepełnosprawnością intelektualną $\mathrm{w}$ stopniu umiarkowanym $\mathrm{w}$ warunkach klasy integracyjnej jest korzystnym rozwiązaniem i czy wyposaży badaną $w$ niezbędną wiedzę i umiejętności? Z opinii pedagoga specjalnego wynika, iż kontynuacja nauki w klasie integracyjnej korzystnie wpłynie na jej rozwój emocjonalny, społeczny oraz na opanowanie technik szkolnych. Jednakże pomimo zapewnien, nadal pojawiają się wątpliwości czy faktycznie edukacja we wspomnianych warunkach zapewni uczennicy możliwość pełnego rozwoju, tj. czy przygotuje badaną (na miarę jej możliwości) do samodzielnego, przyszłego życia $\mathrm{w}$ społeczeństwie? Odpowiedź na to pytanie nie wydaje się być w pełni jednoznaczna, a próba wskazania najlepszej formy kształcenia dla badanej uczennicy na tym etapie (w mojej ocenie) nie w pełni możliwa, gdyż jest to składowa wielu czynników. Wszystko zależy od środowiska rodzinnego uczennicy, jego zaangażowania i świadomości procesu rehabilitacji, od szkoły - pracujących z dzieckiem nauczycieli, od ich podejścia i znajomości problematyki edukacji osób z niepełnosprawnością intelektualną (zwłaszcza w stopniu głębszym), ale w szczególności od specjalistów: psychologów, pedagogów, logopedów, terapeutów pedagogicznych, doradców zawodowych, pracowników poradni psychologiczno-pedagogicznej i ich wzajemnej współpracy. 


\section{Bibliografia}

Bobkowicz-Lewartowska L., Niepetnosprawność intelektualna. Diagnozowanie, edukacja i wychowanie, Harmonia Universalis, Gdańsk 2011.

Czajkowska I., Diagnoza i obserwacja pedagogiczna, [w:] Zajęcia korekcyjno-kompensacyjne w szkole, I. Czajkowska, K. Herda, Wydawnictwa Szkolne i Pedagogiczne Spółka Akcyjna, Warszawa 1989.

Głodkowska J., Poznanie ucznia szkoły specjalnej. Wrażliwość edukacyjna dzieci upośledzonych umystowo w stopniu lekkim: diagnoza i interpretacja, Wydawnictwa Szkolne i Pedagogiczne Spółka Akcyjna, Warszawa 1999.

Górniewicz E., Pedagogiczna diagnoza specyficznych trudności w czytaniu $i$ pisaniu, Wydawnictwo Adam Marszałek, Toruń 2009.

Hanisz J., Grzegorzewska E., Ocena opisowa rozwoju ucznia: ćwiczenia wspomagające i sprawdziany: kształcenie zintegrowane w klasach 1-3, Wydawnictwa Szkolne i Pedagogiczne Spółka Akcyjna, Warszawa 2008.

Jurkiewicz P., Rola B., Model pracy z uczniem upośledzonym umysłowo w stopniu lekkim, [w:] Podniesienie efektywności kształcenia uczniów ze specjalnymi potrzebami edukacyjnymi. Materiały szkoleniowe część II, Ministerstwo Edukacji Narodowej, Warszawa 2010.

Oleńska-Pawlak T., Struktura diagnozy psychopedagogicznej w rewalidacji indywidualnej, [w:] Diagnoza i rewalidacja indywidualna dziecka ze specjalnymi potrzebami edukacyjnymi, red. M. Klaczak, P. Majewicz, Wydawnictwo Naukowe Akademii Pedagogicznej, Kraków 2006.

Siwek H., Możliwości matematyczne uczniów szkoty specjalnej. Zarys teorii i propozycje rozwiązań metodycznych, Wydawnictwa Szkolne i Pedagogiczne, Warszawa 1995.

Skałbania B., Diagnostyka pedagogiczna. Wybrane obszary badawcze $i$ rozwiazania praktyczne, Oficyna Wydawnicza „Impuls”, Kraków 2011.

Sowa J., Pedagogika specjalna w zarysie, Wydawnictwo Oświatowe FOSZE, Rzeszów 1998.

Tanajewska A., Naprawa R., Diagnoza rozwoju ucznia z niepetnosprawnościa intelektualna w stopniu umiarkowanym: karty pracy, Wydawnictwo Harmonia, Gdańsk 2014.

Tkaczyk G., Metodyka nauczania i wychowania poczatkowego w szkole specjalnej, Wydawnictwo Uniwersytetu Marii Curie-Skłodowskiej, Lublin 1997.

Trochimiak B., Gosk U., Diagnoza pedagogiczna uczniów ze specjalnymi potrzebami edukacyjnymi [w:] Dydaktyka specjalna w przygotowaniu do ksztatcenia uczniów ze specjalnymi potrzebami edukacyjnymi: podręcznik akademicki, red. J. Głodkowska, Wydawnictwo Akademii Pedagogiki Specjalnej, Warszawa 2012.

Wójcik-Rudnicka A., Kohut D., Diagnoza psychologiczna i pedagogiczna czy psychopedagogiczna? [w:] Dziecko o specjalnych potrzebach w kręgu interdyscyplinarnej terapii, red. D. Kohut, Oficyna Wydawnicza „Impuls”, Kraków 2013. 